\title{
PENGARUH KARAKTERISTIK PERUSAHAAN TERHADAP CSR PERUSAHAAN PERTAMBANGAN TERDAFTAR DI BEI PERIODE 2017-2019
}

\author{
Vincent Yonathan Kinsey ${ }^{1}$, Urip Santoso ${ }^{2}$ \\ ${ }^{1,2}$ Program Studi Ilmu Administrasi Bisnis, Universitas Katolik Parahyangan, Bandung \\ ${ }^{1}$ yonathankinsey.vincent@gmail.com \\ ${ }^{2}$ urip_santoso@unpar.ac.id
}

\begin{abstract}
ABSTRAK
Tanggung jawab sosial merupakan kontribusi dari perusahaan sebagai tanggung jawab perusahaan kepada lingkungan masyarakat. Perusahaan perseroan terbatas yang sudah terbuka atau terdaftar dalam Bursa Efek Indonesia (BEI) memiliki kewajiban dalam mengungkapkan tanggung jawab sosial. Terutama pada jenis industri yang berhubungan dengan pengolahan sumber daya alam diwajibkan dalam UU nomor 4 tahun 2009 tentang pertambangan mineral dan batu bara pasal 108(1) melaksanakan tanggung jawab sosial. Pengungkapan informasi terdiri dari pengungkapan yang bersifat wajib dan bersifat sukarela. Informasi keuangan merupakan pengungkapan yang bersifat wajib. Keterbukaan informasi keuangan perusahaan ini memicu adanya penelitian yang berfokus kepada karakteristik perusahaan. Penelitian ini berfokus kepada pengaruh karakteristik perusahaan dengan dimensi ukuran perusahaan, ukuran anggota dewan direksi, dan kepemilikan manajerial. Penelitian ini dilakukan pada perusahaan pertambangan di Indonesia yang terdaftar di BEI periode 2017-2019. Hasil penelitian ini membuktikan bahwa total asset ukuran perusahaan, ukuran dewan direksi dan kepemilikan manajerial memiliki pengaruh secara parsial dalam pelaksanaan tanggung jawab sosial serta pengungkapannya. Pengujian secara simultan, ditemukan ukuran perusahaan, ukuran dewan direksi dan kepemilikan manajerial berpengaruh secara signifikan terhadap pengungkapan tanggung jawab sosial.
\end{abstract}

Kata kunci: Ukuran Perusahaan, Ukuran Dewan Direksi, Kepemilikan Manajerial, Tanggung Jawab Sosial (CSR)

\section{ABSTRACT}

Social responsibility is a contribution from a company as a corporate responsibility to the community. Public limited companies that are listed on the Indonesia Stock Exchange (BEI) should disclose their social responsibilities. Especially in the industries that are related to natural resource processing, it is required in Law number 4 of 2009 concerning mineral and coal mining Article 108 (1) to carry out social responsibility. Disclosure of information consists of mandatory and voluntary disclosures. Financial information is a mandatory disclosure. This disclosure of company financial information triggers this research that focuses on the characteristics of the company. This research focuses on the effect of firm characteristics with dimensions of company size, board member size, and managerial ownership. This research was conducted on mining companies in Indonesia listed on the BEI for the period 2017-2019. The results prove that the total assets of the company, the size of the board of directors, and managerial ownership have a partial influence on the implementation, and disclosure of social responsibility. Based on the simultaneous testing, the size of the company, the size of the board of directors, and managerial ownership have a significant effect on the disclosure of social responsibility. Keywords: Company Size, Board of Directors Size, Managerial Ownership, Social Responsibility (CSR)

\section{PENDAHULUAN}

Dengan strategi dan program Corporate Social Responsibility (CSR) perusahaan memberikan pertanggungjawaban ke masyarakat dan stakeholder serta investor. Tanggung jawab sosial termasuk ke dalam bidang ekonomi, hukum, etika yang harus dipenuhi dalam rangka pemenuhan ekspektasi stakeholders. Pengungkapan tanggung jawab sosial dilakukan agar perusahaan mencapai profit yang diinginkan dalam rangka meningkatkan perekonomian lingkungan (Salehi, Tarighi, \& Rezanezhad, 2017, pp. 399-340).

Penelitian dilakukan dalam menguji apakah terdapat pengaruh karakteristik perusahaan terhadap pengungkapan CSR. Karakteristik perusahaan sendiri dilihat dari internal perusahaan seperti ukuran perusahaan, struktur anggota dewan direksi, kepemilikan saham manajerial. Penelitian ini dilakukan pada sepuluh perusahaan Tbk kelompok perusahaan pertambangan di Indonesia, selama periode 2017 hingga 2019. Data yang digunakan adalah data sekunder yang diperoleh dari web perusahaan dan dari IDX.co.id. Penelitian ini dengan topik pengaruh karakteristik perusahaan 
terhadap pengungkapan tanggung jawab sosial.

Perusahaan perseroan terbatas diwajibkan melaksanakan dan mengungkapkan tanggung jawab sosial yang diatur dalam Undang - Undang Nomor 40 Tahun 2007 tentang Perseroan Terbatas. Selain dalam diatur dalam undang-undang, perusahaan dan organisasi diharapkan dapat menerapkan tanggung jawab dalam rangka hasil timbal balik kepada lingkungan sekitar. Perusahaan secara tidak langsung sudah menggunakan bahan baku yang didapat dari alam atau lingkungan. Oleh karena itu dalam rangka memberikan timbal balik kepada lingkungan perusahaan diwajibkan menerapkan CSR. Termasuk kepada perusahaan di bidang pertambangan yang diwajibkan oleh pemerintah menerapkan CSR. Hal ini diatur dalam Undang Undang nomor 4 tahun 2009 pasal 108 ayat (1). Oleh karena itu dalam penelitian ini penulis memilih kelompok perusahaan perseroan terbatas pertambangan. Hal ini karena perusahaan pertambangan di Indonesia diwajibkan melaksanakan pengungkapan tanggung jawab sosial.

\section{KAJIAN TEORI}

\section{Good Corporate Governance (GCG)}

Penerapan GCG diperlukan dalam mendorong terciptanya pasar yang efisien, transparan dan konsisten terhadap peraturan perundang-undangan. Pedoman GCG yang berisikan ketiga pilar yaitu pertama adalah negara sebagai penegak hukum peraturan. Kedua, dunia usaha sebagai pelakunya harus menaati dan menerapkan GCG sebagai pedoman dasar. Terakhir adalah masyarakat diminta untuk menunjukkan kepedulian dan kontrol sosial atas dampak dari keberadaan perusahaan (Komite Nasional Kebijakan Governance, 2006, p. 3).

Tujuan dari tata kelola perusahaan yaitu membangun lingkungan yang transparan, akuntabilitas, serta dapat dipercaya. Setiap prinsip diatas diperlukan dalam mencapai investasi jangka panjang, stabilitas keuangan, dan peningkatan reputasi perusahaan. Prinsip diatas dapat mengidentifikasi tata kelola perusahaan yang baik dan membantu implementasi GCG tingkat nasional (International Finance Corporation, 2018, pp. 35-
36).

\section{Teori Keagenan (Agency Theory)}

Tata kelola perusahaan didasarkan kepada teori keagenan, dimana pengawasan dan pengendalian perusahaan dibantu. Manajemen perusahaan dipandang tidak dapat dipercaya dalam melakukan kinerja secara baik bagi kepentingan pemegang saham dan shareholders. Pengelolaan perusahaan sendiri harus diawasi dan dikendalikan dalam memastikan kinerja para agen atau manajemen mematuhi peraturan yang ada. Manajemen menginginkan pengungkapan tanggung jawab sosial yang kecil agar mendapatkan laba yang lebih besar agar menyenangkan shareholder. Tetapi di samping itu dari pemerintah mewajibkan penerapan tanggung jawab sosial oleh setiap perusahaan perseroan terbatas. Hal ini menyebabkan konflik terjadi karena manajemen dinilai tidak bisa menjalankan tugasnya dengan benar. Dari sini timbullah agency cost dikarenakan konflik antara manajemen dan shareholder (Daniri, 2014, hal. 5-6).

Dapat disimpulkan agency cost ini timbul dikarenakan adanya manajemen yang dipandang tidak dapat dipercaya sepenuhnya. Dalam melakukan tugas dan tanggung jawabnya memang sudah ada yang mengawasinya yaitu dewan direksi. Tetapi tidak cukup hanya dewan direksi yang mengawasi kinerja manajemen. Stakeholder merasa perlu adanya pembentukan divisi yang mengawasi dan mengendalikan dalam memastikan pematuhan peraturan yang ada oleh manajemen. Sehingga perusahaan membuat divisi atau organisasi agency yang bertugas mengurangi biaya lainnya yang timbul dikarenakan ketidakpatuhan manajer.

\section{Teori Legitimasi (Legitimacy Theory)}

Tata kelola perusahaan di teori legitimasi adalah langkah perusahaan membuat suatu tindakan yang nantinya diperkirakan dapat diterima oleh lingkungan masyarakat. Tindakan yang dibuat itu nantinya akan berdampak kepada kegiatan operasional perusahaan serta lingkungan masyarakat. Teori legitimasi dimana perusahaan yang harus berusaha mendapatkan pengakuan publik terkait kinerja yang dilakukan sesuai dengan keinginan publik. Besaran sumber daya yang 
dimiliki oleh perusahaan akan mempengaruhi tingkat pengakuan legitimasi oleh seluruh pemangku kepentingan. Dengan menerapkan pengungkapan tanggung jawab sosial akan didapat legitimasi, serta mengungkapkan lebih banyak dampak sosial lingkungan atas aktivitas laba perusahaan (Krisna \& Suhardianto, 2016, p. 120).

Dapat disimpulkan dengan melakukan pengungkapan dapat mempengaruhi kegiatan operasional perusahaan serta lingkungannya. Dengan melakukan pengungkapan dapat mempengaruhi tingkatan legitimasi suatu perusahaan. Tingkatan legitimasi ini akan mempengaruhi juga tingkat penerimaan masyarakat atau lingkungan terhadap perusahaan.

\section{Teori Stakeholder (Stakeholder Theory)}

Konsep stakeholder theory dalam tata kelola perusahaan sering dikaitkan kepada koordinasi dengan seluruh pihak terlibat dalam perusahaan dalam rangka membangun keberlanjutan perusahaan. Manajemen diharapkan agar melakukan keseimbangan kepentingan antara pemegang saham serta stakeholder. Hal ini diharapkan agar tidak mengganggu kinerja perusahaan dan benturan kepentingan lainnya. Dengan membuat sistem yang efektif dalam memudahkan akses mendapatkan informasi dapat membantu menghindari benturan. Stakeholder juga dapat mempengaruhi kebijakan perusahaan, tidak hanya shareholder saja. Stakeholder menginginkan sustainability perusahaan dengan menciptakan keseimbangan kepentingan bagi seluruh pemangku kepentingan (Daniri, 2014, hal. 57-60).

Dapat disimpulkan pada teori ini stakeholder menginginkan sistem yang dapat membantu kinerja manajemen lebih baik lagi. Dengan adanya koordinasi di antara para manajemennya. Diharapkan dapat menjadikan kinerja perusahaan yang sustainability. Selanjutnya diharapkan juga agar minim terjadinya benturan atau permasalahan terjadi di dalam perusahaan oleh pihak manajemen.

\section{Teori Karakteristik Perusahaan}

Menurut Krisna \& Suhardianto (2016), karakteristik perusahaan terbagi kedalam beberapa dimensi. Setiap dimensi ini memiliki pengaruh terhadap pengungkapan tanggung jawab sosial. Dimensi pertama adalah ukuran perusahaan, besarnya suatu perusahaan mempengaruhi upaya perusahaan dalam mendapatkan legitimasi. Dimensi kedua adalah kepemilikan saham manajerial, persentase yang tinggi akan mengakibatkan pengawasan oleh pihak investor agar tidak terjadi perilaku oportunistik manajer. Opportunistic manajer adalah kegiatan yang dilakukan manajer dalam menahan cash perusahaan agar mereka lebih mendapatkan keuntungan lebih besar, kondisi ini terjadi bila kepemilikan manajerial lebih besar dibanding kepemilikan pemegang saham lainnya. Dimensi selanjutnya adalah ukuran dewan direksi, dimana besar ukuran dewan direksi mempengaruhi pelaksanaan tanggung jawab sosial (Krisna \& Suhardianto, 2016, pp. 120-121).

Dapat diambil kesimpulan, karakteristik perusahaan merupakan kumpulan beberapa dimensi yang dapat berpengaruh baik pada perusahaan dan lingkungan. Karakteristik perusahaan yaitu dimensi-dimensi yang memberikan pengaruh terhadap pengungkapan tanggung jawab sosial. Berdasarkan struktur jenis kepemilikan. Selanjutnya dari kinerja terdapat dimensi profitabilitas, jenis perusahaan. Terakhir berdasarkan struktur pasar yaitu dimensi jenis industri (Krisna \& Suhardianto, 2016; Husaini \& Trinesia, 2020). Karakteristik perusahaan pada penelitian ini dapat diukur menggunakan dimensi ukuran perusahaan, ukuran dewan direksi, dan kepemilikan manajerial. Dimensi pertama adalah ukuran perusahaan, besarnya suatu perusahaan mempengaruhi upaya perusahaan dalam mendapatkan legitimasi. Dimensi kedua adalah ukuran dewan direksi dimana besar ukuran dewan direksi mempengaruhi pelaksanaan tanggung jawab sosial. Dimensi ketiga adalah kepemilikan manajerial, persentase yang tinggi akan mengakibatkan pengawasan oleh pihak investor agar tidak terjadi perilaku oportunistik manajer. Penulis menggunakan ketiga dimensi dari banyaknya dimensi dikarenakan ketiga dimensi menggambarkan karakteristik perusahaan menurut penelitian sebelumnya. terdapat dimensi ukuran perusahaan, leverage, dan 


\section{Ukuran Perusahaan}

Perusahaan yang memiliki sumber daya atau total aset yang besar akan berupaya semakin besar untuk mendapatkan legitimasi dari seluruh pemangku kepentingan. Legitimasi dapat diperoleh dengan melaksanakan tanggung jawab sosial dan mengungkapkannya dalam laporan tahunan. Perusahaan besar memiliki political visibility yang tinggi sehingga transparansi kepada publik semakin meningkat. Political visibility adalah biaya-biaya yang dikeluarkan dalam pengungkapan terkait dengan aspek politik sosial dan lingkungan (Krisna \& Suhardianto, 2016, p. 120).

Menurut Weygandt, Kimmel, \& Kieso (2015) aset adalah sumber daya yang dimiliki oleh setiap jenis bisnis. Aset akan digunakan dalam aktivitas produksi dan penjualan. Karakteristik aset adalah memberikan manfaat untuk masa mendatang. Total aset harus seimbang dengan jumlah liabilitas dan ekuitas dalam laporan keuangan (Weygandt, Kimmel, \& Kieso, 2015)

Perusahaan yang besar memiliki sumber daya yang besar serta aktivitas yang kompleks. Besarnya perusahaan mempengaruhi tingkat pengungkapan informasi dalam laporan tahunan. Pengungkapan ini dilakukan untuk mengurangi biaya keagenan dan biaya politik perusahaan, serta mencapai legitimasi. Perusahaan dapat terus beroperasi dengan adanya legitimasi dari lingkungannya (Krisna \& Suhardianto, 2016). Pengukuran menggunakan total aset perusahaan, yang diambil dari laporan tahunan periode 20172019 bersumber dari idx.co.id serta web perusahaan. Pengukuran ukuran perusahaan melalui total aset dianggap menggambarkan karakteristik perusahaan.

\section{Ukuran Dewan Direksi}

Selanjutnya untuk ukuran dewan direksi sendiri bergantung pada banyaknya tugas dan tanggung jawab dewan direksi, serta tujuan perusahaan. Berdasarkan best practice jumlah ukuran dewan direksi terdiri dari dua sampai tiga orang dan sudah termasuk dengan presiden direktur. Setiap anggotanya ditunjuk pada rapat umum pemegang saham dan diberikan tugas sesuai dengan tujuan pada anggaran dasar perusahaan. Setiap direksi terpilih berdasarkan kriteria perusahaan masing-masing. Perbedaan setiap anggota dewan direksi menjadikan entitas dengan sumber daya dan kinerja yang lebih baik pada pengungkapan material (Matuszak, Różańska, \& Macuda, 2019, p. 82).

Tugas dan kewajiban dewan direksi terbagi kedalam lima elemen yaitu manajemen, manajemen risiko, pengendalian internal, hubungan masyarakat, dan tanggungjawab sosial. Direksi membuat rencana dan fokus yang jelas untuk strategi tanggung jawab sosial, dalam rangka memberikan dampak positif bagi masyarakat dan lingkungan (International Finance Corporation, 2018, pp. 206-208).

\section{Kepemilikan Manajerial}

Manajemen yang memiliki saham yang cukup besar dapat mendominasi perusahaan. Kepemilikan manajerial menjadikan manajemen dominan di perusahaan dan dapat membuat keputusan pengungkapan informasi. Hal ini membantu dalam pembuatan keputusan lebih cepat baik strategi dan peraturan. Tetapi dengan bertambahnya kepemilikan manajerial akan membuat perusahaan harus mengungkapkan informasi tanggung jawab sosial lebih lagi. Hal ini juga dipengaruhi oleh objek penelitian. Jika objek penelitian bersifat empiris maka bertambahnya kepemilikan manajerial memperkecil pengungkapan tanggung jawab sosial (Agustia, Dianawati, \& A., 2018, p. 68).

Dapat disimpulkan, kepemilikan saham manajerial akan mempengaruhi pengungkapan tanggung jawab sosial. Semakin besar kepemilikan manajerial pada suatu perusahaan semakin besar pengaruh keterlibatan baik manajer dan dewan direksi dalam melakukan pengungkapan. Sehingga sulit bagi pemegang saham minoritas dan mayoritas dalam memberikan pengaruh kepada tindakan manajer dan direksi perusahaan. Semakin besar kepemilikan manajerial meningkatkan kebutuhan dana perusahaan dalam melakukan pengungkapan tanggung jawab sosial (Nurleni, Bandang, Darmawati, \& Amiruddi, 2017; Agustia, Dianawati, \& A., 2018). Dalam penelitian ini, kepemilikan manajerial menggunakan 
pengukuran berdasarkan penelitian Arif Rahman. Pengukuran kepemilikan manajerial dilakukan berdasarkan persentase saham manajerial yang dimiliki oleh manajer pada suatu perusahaan, diambil dari laporan tahunan periode 2017 - 2019 bersumber dari idx.co.id serta web perusahaan. Pengukuran kepemilikan manajerial berdasarkan persentase dianggap menggambarkan karakteristik perusahaan dari hasil kepemilikan oleh manajemen dan dewan direksi.

\section{Tanggung jawab Sosial Perusahaan}

Tanggung jawab sosial menurut Sri Wahjuni (2012) adalah aktivitas yang dilakukan oleh perusahaan kepada masyarakat sebagai bentuk kedermawanan sosial. Perusahaan yang memiliki orientasi pada konsumen akan mengungkapkan informasi pertanggungjawaban sosialnya dengan benar. Pengungkapan informasi akan dilakukan dengan benar karena perusahaan ingin meningkatkan citra dan secara tidak langsung dapat meningkatkan penjualan. Aktivitas pengungkapan dan pelaporan informasi harus diterima oleh seluruh stakeholder. Pengungkapan tanggung jawab sosial ini akan mempengaruhi keputusan pemilik serta investor dalam melakukan investasi dan para stakeholder (Latifah, 2012, p. 66).

Tanggung jawab sosial adalah kegiatan yang dilakukan perusahaan dengan menerapkan tindakan sosial dan tanggung jawab lingkungan dalam meningkatkan performa perusahaan ( (Herman, 2018; Ismail, 2020; Latifah, 2012; Kabir \& Thai, 2017; Kabir \& Thai, 2017). Selanjutnya untuk pengukuran tanggung jawab sosial digunakan sebelas indikator atau subjek yaitu tata kelola organisasi, HAM, praktik ketenagakerjaan, lingkungan, praktik operasional yang adil, konsumen, pembangunan sosial, ekonomi, pendidikan, kesehatan dan keagamaan. Selanjutnya dari sebelas subjek tersebut dipecah kembali ke beberapa isu. Setelah dipecah ke beberapa isu dipecah kembali ke beberapa contoh indikator Sehingga dengan ini penulis menjadikan penelitian baru dengan indikator gabungan dari ketiga penelitian sebelumnya yaitu penelitian Herman (2018), Latifah (2012) dan Thai (2017).

\section{METODOLOGI}

Penelitian ini menggunakan pendekatan deduktif-kuantitatif karena pendekatan ini digunakan ketika suatu data dapat diukur dan diverifikasi dan bersifat fakta (Sugiyono, 2017, pp. 7,10$)$. Teknik pengumpulan data yang penulis gunakan adalah metode unobtrusive. Metode unobtrusive tidak membutuhkan peneliti untuk berinteraksi secara langsung dengan individu, kelompok dan organisasi yang menjadi objek penelitian (Sekaran \& Bougie, 2016, hal. 112-113). Pencarian data di website ini disebut sebagai data sekunder. Data sekunder adalah data yang sudah pernah dikumpulkan oleh orang lain, dan organisasi atau perusahaan. Data sekunder berisi dokumen - dokumen yang terdapat dalam website atau sudah dipublikasikan (Sekaran \& Bougie, 2016, hal. 37). Data akan diolah menggunakan aplikasi software SPSS dan menggunakan analisis uji asumsi klasik. Penelitian yang dilakukan oleh penulis menggunakan tiga teknik analisis data yaitu deskriptif statistik, regresi linier berganda, dan uji asumsi klasik. Pengukuran untuk tanggung jawab sosial menggunakan jumlah indikator (80 Indikator) yang diungkapkan perusahaan pada tanggung jawab sosial di akhir periode.

Data diambil dari laporan tahunan periode 2017 - 2019 bersumber dari idx.co.id serta web perusahaan. 


\section{Operasionalisasi Variabel}

Tabel 1. Operasionalisasi Variabel

\begin{tabular}{|c|c|c|c|}
\hline $\begin{array}{l}\text { Variabel } \\
\text { Independen }\end{array}$ & Definisi Variabel & Dimensi & Indikator \\
\hline \multirow[t]{3}{*}{$\begin{array}{l}\text { Karakteristik } \\
\text { Perusahaan }\end{array}$} & \multirow{3}{*}{$\begin{array}{l}\text { Karakteristik perusahaan adalah dimensi - } \\
\text { dimensi yang memberikan pengaruh kepada } \\
\text { tanggung jawab sosial. Dimensi ini adalah } \\
\text { ukuran perusahaan yang memberikan pengaruh } \\
\text { dari total aset yang dimiliki. Total aset yang } \\
\text { dimiliki dijadikan sebagai sumber daya } \\
\text { perusahaan dalam mendapatkan legitimasi } \\
\text { melalui pengungkapan tanggung jawab sosial. } \\
\text { Dimensi selanjutnya adalah ukuran dewan } \\
\text { direksi, dimana dewan direksi adalah tingkat } \\
\text { tertinggi manajemen yang berfungsi } \\
\text { memperoleh legitimasi. Besaran anggota dewan } \\
\text { direksi akan mempengaruhi pencapaian suatu } \\
\text { kesepakatan dalam melakukan tanggungjawab } \\
\text { sosial. Dimensi ketiga adalah kepemilikan } \\
\text { manajerial, dimana akan memberikan pengaruh } \\
\text { dalam membuat keputusan pengungkapan } \\
\text { informasi. Hal ini dipengaruhi oleh manajemen } \\
\text { sebagai pemilik saham (Krisna \& Suhardianto, } \\
\text { 2016; Weygandt, Kimmel, \& Kieso, 2015; } \\
\text { Kabir \& Thai, 2017; Nurleni, Bandang, } \\
\text { Darmawati, \& Amiruddi, 2017; Agustia, } \\
\text { Dianawati, \& A., 2018). }\end{array}$} & $\begin{array}{l}\text { Ukuran } \\
\text { Perusahaan }\end{array}$ & $\begin{array}{l}\text { Besaran perusahaan diukur } \\
\text { berdasarkan total aset } \\
\text { suatu perusahaan dalam } \\
\text { laporan tahunan periode } \\
2017-2019\end{array}$ \\
\hline & & $\begin{array}{ll}\text { Ukuran Dewan } \\
\text { Direksi }\end{array}$ & $\begin{array}{l}\text { Besaran anggota dewan } \\
\text { direksi diukur berdasarkan } \\
\text { jumlah anggota dewan } \\
\text { direksi suatu perusahaan } \\
\text { dalam laporan tahunan } \\
\text { periode } 2017-2019\end{array}$ \\
\hline & & $\begin{array}{l}\text { Kepemilikan } \\
\text { Manajerial }\end{array}$ & $\begin{array}{l}\text { Kepemilikan saham pada } \\
\text { manajer dan dewan direksi } \\
\text { diukur berdasarkan } \\
\text { presentase kepemilikan } \\
\text { manajerial dalam laporan } \\
\text { tahunan periode } 2017 \text { - } \\
2019\end{array}$ \\
\hline $\begin{array}{l}\text { Variabel } \\
\text { Dependen }\end{array}$ & Definisi Variabel & Dimensi & Indikator \\
\hline $\begin{array}{l}\text { Tanggungjaw } \\
\text { ab Sosial }\end{array}$ & $\begin{array}{l}\text { Tanggung jawab sosial adalah kegiatan yang } \\
\text { dilakukan perusahaan dengan menerapkan } \\
\text { tindakan sosial dan tanggung jawab lingkungan } \\
\text { dalam meningkatkan performa perusahaan } \\
\text { (Herman, 2018; Ismail, 2020; Latifah, 2012; } \\
\text { Kabir \& Thai, 2017). }\end{array}$ & - & $\begin{array}{l}\text { Persentase indikator yang } \\
\text { diungkapkan perusahaan } \\
\text { dibandingkan dengan } 80 \\
\text { indikator }\end{array}$ \\
\hline
\end{tabular}

Sumber: Laporan Tahunan 2017-2019

\section{Teknik Analisis Data}

Unit Sampling pada penelitian ini adalah organisasi. Penelitian ini menggunakan unit sampling organisasi karena dilakukan perbandingan departemen-departemen dalam organisasi perusahaan. Selanjutnya penelitian ini bertujuan untuk mempelajari kelompok organisasi dalam setiap kegiatan yang dilakukan (Sekaran \& Bougie, 2016, hal. 102-103). Pada tahapan pengumpulan sampel sendiri digunakan metode purposive sampling. Purposive sampling adalah pengambilan sampel didasarkan kepada apa saja unsur - unsur yang dikehendaki peneliti (Sekaran \& Bougie, 2016, hal. 248).

Pengujian hipotesis terbagi kedalam beberapa tahapan dimulai dari pengembangan hipotesis sampai pengujian hipotesis. Berikut adalah tahapan menurut Sekaran dan Bougie (2016):
Mengembangkan dua hipotesis yaitu hipotesis null dan hipotesis alternatif. Hipotesis null dikembangkan untuk nantinya ditolak, dalam rangka mendukung hipotesis alternatif. Hipotesis null diasumsikan benar dipengembangan hipotesis dan akan dinyatakan salah dalam pengujian hipotesis. Pengujian hipotesis ini menggunakan analisis regresi linier berganda (Sekaran \& Bougie, 2016, hal. 301). Berikut ini penulis lampirkan beberapa hipotesis baik secara simultan dan parsial yang dikembangkan untuk diujikan :

a) Hipotesis Secara Parsial
i) $\mathrm{H}_{0}: \beta_{1}=0$ :
Ukuran perusahaan tidak berpengaruh terhadap pengungkapan tanggung jawab sosial .
$\mathrm{H}_{\mathrm{a}}: \beta_{1} \neq 0$ : Ukuran perusahaan berpengaruh terhadap pengungkapan tanggung jawab sosial.


ii) $\mathrm{H}_{0}: \beta_{2}=0$ : Ukuran dewan direksi tidak berpengaruh terhadap pengungkapan tanggung jawab sosial.

$\mathrm{H}_{\mathrm{a}}$ : $\beta_{2} \neq 0$ : Ukuran dewan direksi berpengaruh terhadap pengungkapan tanggung jawab sosial.

iii) $\mathrm{H}_{0}: \beta_{3}=0: \quad$ Kepemilikan manajerial tidak berpengaruh terhadap pengungkapan tanggung jawab sosial.

$\mathrm{H}_{\mathrm{a}}: \beta_{3} \neq 0: \quad$ Kepemilikan manajerial berpengaruh terhadap pengungkapan tanggung jawab sosial.

b) Hipotesis Secara Simultan

$\mathrm{H}_{0}$ : Semua $\beta_{\mathrm{i}}=0$ : Ukuran perusahaan, ukuran dewan direksi, dan kepemilikan manajerial secara simultan tidak berpengaruh terhadap pengungkapan tanggung jawab sosial.

$\mathrm{H}_{\mathrm{a}}$ : Ada $\beta \mathrm{i} \neq 0$ : Ukuran perusahaan, ukuran dewan direksi, dan kepemilikan manajerial secara simultan berpengaruh terhadap pengungkapan tanggung jawab sosial.

\section{HASIL PENELITIAN DAN PEMBAHASAN}

Penelitian ini dilakukan pada 10 perusahaan pertambangan yang tercatat di Bursa Efek Indonesia sebagai sampel penelitian. Data yang dikumpulkan selama periode 3 tahun yaitu dari tahun 2017 hingga tahun 2019. Guna menjawab permasalahan penelitian, berikut ini akan dianalisis data ukuran perusahaan, ukuran dewan direksi, kepemilikan manajerial, dan pengungkapan tanggung jawab sosial masingmasing perusahaan. Pertama adalah pembahasan dari variabel dependen, yaitu tanggung jawab sosial. Pada tabel 2 ditunjukkan data pengungkapan tanggung jawab sosial. Dilihat dari Tabel 2, berdasarkan analisis deskriptif diketahui perusahaan pertambangan yang terdaftar tahun 2017 - 2019 memiliki rata - rata melakukan pengungkapan tanggung jawab sosial dibawah 30 persen. Artinya kebanyakan perusahaan pertambangan terdaftar pada tahun 2017 - 2019 melaksanakan pengungkapan tanggung jawab sosial, tetapi masih minim pengungkapan yang dilakukannya. Pada tahun 2017 rata - rata pengungkapan tanggung jawab sosial hanya $26 \%$ dengan 5 perusahaan yang diatas rata - rata. Kelima perusahaan ini adalah ANTM (52\%), CITA (27\%), TINS (42\%), BSSR (27\%) dan BYAN (32\%). Adapun perusahaan yang memiliki persentase pengungkapan tanggung jawab sosial dibawah rata-rata terdapat 5 perusahaan yaitu DKFT (24\%), PSAB (14\%), APEX (21\%), ARTI (14\%), dan PKPK (4\%). Pada tahun 2018, rata rata pengungkapan tanggung jawab sosial sebesar $30 \%$ dan masih 5 perusahaan yang mengungkapan tanggung jawab sosial diatas rata-rata. Kelima perusahaan tersebut sama seperti perusahaan di tahun 2017 tetapi hanya berbeda satu perusahaan yaitu DKFT (32\%), sisanya tetap sama yaitu ANTM (70\%), TINS (42\%), BSSR (26\%), BYAN( 33\%). Sedangkan di tahun 2019 perusahaan yang memiliki presentase di atas ratarata pengungkapan sebesar $33 \%$ terdapat 4 perusahaan yaitu ANTM (70\%), TINS (42\%), BSSR (26\%), BYAN( 33\%).

Tabel 2. Data Pengungkapan Tanggung Jawab Sosial (CSR)

\begin{tabular}{|c|c|c|c|c|}
\hline \multirow[b]{2}{*}{ No } & \multirow{2}{*}{$\begin{array}{c}\text { Kode } \\
\text { Perusahaan } \\
\end{array}$} & \multicolumn{3}{|c|}{$\begin{array}{c}\text { Pengungkapan CSR } \\
(\%)\end{array}$} \\
\hline & & 2017 & 2018 & 2019 \\
\hline 1 & ANTM & 52,56 & 60,67 & 58,97 \\
\hline 2 & CITA & 26,92 & 26,92 & 25,64 \\
\hline 3 & DKFT & 24,36 & 27,77 & 26,92 \\
\hline 4 & PSAB & 14,10 & 12,82 & 11,54 \\
\hline 5 & TINS & 42,31 & 43,16 & 43,59 \\
\hline 6 & APEX & 21,79 & 18,80 & 17,95 \\
\hline 7 & ARTI & 14,10 & 17,09 & 17,95 \\
\hline 8 & PKPK & 3,85 & 8,55 & 16,67 \\
\hline 9 & BSSR & 26,92 & 32,90 & 33,33 \\
\hline 10 & BYAN & 32,05 & 32,90 & 33,33 \\
\hline \multicolumn{2}{|r|}{ Rata-Rata } & 25,90 & 30,00 & $\mathbf{3 0 , 8 5}$ \\
\hline \multicolumn{2}{|r|}{ Std. Deviasi } & 14,16 & 18,63 & 14,39 \\
\hline \multicolumn{2}{|r|}{ Tertinggi } & 52,56 & 70,51 & $\mathbf{5 8 , 9 7}$ \\
\hline \multicolumn{2}{|r|}{ Terendah } & $\mathbf{3 , 8 5}$ & 5,13 & 60,67 \\
\hline
\end{tabular}

Sumber : Hasil pengolahan data dari Laporan Tahunan periode 2017 - 2019

Pada tahun 2019 terdapat 6 perusahaan yang mengungkapkan tanggung jawab sosial dibawah rata - rata. Keenam perusahaan ini adalah CITA (28\%), DKFT (26\%), PSAB (11\%), APEX (17\%), ARTI (18\%), dan PKPK (16\%). 
Selanjutnya dilihat dari tabel 2 periode 2017-2019 hanya 4 perusahaan yang mengungkapkan tanggung jawab sosial diatas rata -rata setiap tahunnya. Keempat perusahaan ini adalah ANTM, TINS, BSSR dan BYAN.

Hasil pengolahan data pada tabel 2 dapat diartikan bahwa perusahaan pertambangan sudah menaati Undang Nomor 40 Tahun 2007 pasal 74 tentang Perseroan Terbatas. Perusahaan pertambangan sudah menerapkan visi dan misi perusahaan serta menjalankan good corporate governance, dimana menerapkan tanggung jawab sosial lingkungan dan sosial. ANTM merupakan perusahaan yang mengungkapkan tanggung jawab sosial lebih dari 50 persen. Pada tahun 2017 pengungkapan tanggung jawab sosial mencapai 52\%, tahun 2018 mencapai $70 \%$ dan tahun 2019 mencapai 58\%. Dengan ini ANTM mendapatkan beberapa keuntungan dari penerapan pengungkapan tanggung jawab sosial dengan skala luas. Pertama membantu meningkatkan kinerja finansial dan meningkatkan profitabilitas. Kedua dapat meningkatkan akuntabilitas, assessment. Selanjutnya membantu meningkatkan kinerja dan komitmen karyawan karena mereka merasa dihargai dan diperhatikan. Keempat dapat membantu menurunkan resiko pertikaian dalam organisasi. Terakhir membantu meningkatkan reputasi perusahaan (Herman, 2018, p. 268).

Selanjutnya adalah pembahasan dari unsur karakteristik perusahaan yang adalah variabel independen.

Tabel 3. Gambaran Data Ukuran Perusahaan

\begin{tabular}{|c|c|c|c|c|}
\hline \multirow{2}{*}{ No } & \multirow{2}{*}{$\begin{array}{c}\text { Kode } \\
\text { Perusah } \\
\text { aan }\end{array}$} & \multicolumn{3}{|c|}{ Total Aset (Juta Rupiah) } \\
\hline & & 2017 & 2018 & 2019 \\
\hline 1 & ANTM & 30.014 & 33.306 & JU. \\
\hline 2 & & & & \\
\hline 3 & & & & \\
\hline 4 & & & & \\
\hline 5 & TII & 9,00 & 15.1 & \\
\hline 6 & & & 7.4 & \\
\hline 7 & & & & \\
\hline 8 & $\bar{P}$ & & & \\
\hline 9 & & & & \\
\hline $\begin{array}{l}1 \\
0\end{array}$ & D 1781 & ,21 & 16.6 & 17. \\
\hline \multicolumn{2}{|c|}{ Rata-Rata } & $8.470 .175,14$ & 7,30 & 10.081.428,06 \\
\hline \multicolumn{2}{|c|}{$\begin{array}{c}\text { Std. } \\
\text { Deviasi }\end{array}$} & & 10.1 & 9.9910 \\
\hline \multicolumn{2}{|c|}{ Tertinggi } & 30.0 & 33.31 & $4.907,73$ \\
\hline \multicolumn{2}{|c|}{ Terendah } & $137.363,30$ & $127.894,51$ & $71.655,56$ \\
\hline
\end{tabular}

Sumber : Hasil pengolahan data dari Laporan Tahunan periode 2017 - 2019
Tabel 3 menunjukkan gambaran data ukuran perusahaan. Analisis deskriptif menghasilkan bahwa hampir semua perusahaan pertambangan memiliki total aset yang besar. Jumlah aset yang terbesar dimiliki oleh ANTAM yang mencapai 30 triliun rupiah. Sedangkan total asset terkecil dimiliki oleh PKPK yang memiliki total aset kurang dari 200 milyar rupiah. Artinya hampir semua perusahaan pertambangan berukuran besar memiliki total asset $>1$ triliun rupiah, dan hal ini mempengaruhi luas pengungkapan tanggung jawab sosial. Sejalan dengan kajian teori, perusahaan yang besar memiliki sumber daya yang besar serta aktivitas yang kompleks. Besarnya perusahaan mempengaruhi tingkat pengungkapan informasi dalam laporan tahunan. Ukuran perusahaan yang besar akan lebih besar kemungkinan untuk dipengaruhi oleh publik. Pengaruh yang diberikan publik membuat perusahaan lebih sering mengungkapkan informasi untuk mengurangi biaya politik sebagai bentuk akan tanggung jawab sosial.

Pengujian hipotesis secara parsial ditemukan adanya pengaruh ukuran perusahaan terhadap pengungkapan tanggung jawab sosial perusahaan pertambangan terdaftar. Penerimaan HA sejalan dengan penelitian yang dilakukan oleh Krisna \& Suhardianto (2016), dan Husaini (2020), yang dimana terdapat pengaruh ukuran perusahaan terhadap pengungkapan tanggung jawab sosial. Menurut Husaini (2020) perusahaan berukuran besar cenderung untuk melakukan pengungkapan tanggung jawab sosial lebih luas, dan memiliki aktivitas yang kompleks dan lebih memberikan dampak besar kepada lingkungan dan masyarakat (Husaini \& Trinesia, 2020, p. 95). Aset adalah sumber daya yang dimiliki oleh setiap jenis bisnis. Aset akan digunakan dalam aktivitas produksi dan penjualan. Karakteristik aset adalah memberikan manfaat untuk masa mendatang. Total aset harus seimbang dengan jumlah liabilitas dan ekuitas dalam laporan keuangan. Artinya ukuran perusahaan dengan total aset yang besar cenderung mengungkapkan tanggung jawab sosial lebih luas. Dengan kata lain jika ukuran perusahaan sedang dan kecil cenderung mengungkapkan tanggung jawab sosial lebih sedikit. Adanya pengaruh 
ukuran perusahaan terhadap pengungkapan tanggungjawab sosial juga dibuktikan oleh kondisi kelompok perusahaan pertambangan terdaftar.

Total aset diatas rata-rata 8,4 triliun rupiah. Pada tahun 2017 ditemukan 4 perusahaan. Perusahaan dengan total aset diatas rata - rata adalah ANTM ( $>30$ triliun rupiah), PSAB ( $>12$ triliun rupiah), TINS ( $>11$ triliun rupiah), dan , BYAN (>12 triliun rupiah). Terdapat 1 perusahaan yang memiliki total aset $>8,4$ triliun rupiah tetapi melakukan pengungkapan CSR dibawah rata - rata yaitu PSAB dengan persentase pengungkapan tanggung jawab sosial di tahun 2017 sebesar (14\%). Adapun total aset perusahaan dalam jutaan rupiah yang dibawah rata - rata pada tahun 2017 terdapat 6 perusahaan. Keenam perusahaan ini adalah BSSR ( $>2,8$ triliun rupiah), CITA $(>2,6$ triliun rupiah), DKFT $(>2,2$ triliun rupiah), APEX ( $>7,8$ triliun rupiah), ARTI $(>2,5$ triliun rupiah), PKPK (>137 miliar rupiah). Jika dihubungkan kepada pengungkapan tanggung jawab sosial terdapat 1 perusahaan yang memenuhi HA dimana ukuran perusahaan berpengaruh terhadap CSR. BSSR memiliki persentase CSR yang cukup tinggi $(26,92)$ walaupun total aset yang dimiliki di bawah rata-rata. Akan tetapi angka CRS BSSR lebih kecil dibandingkan dengan ANTM dan TINS. Hal ini sesuai dengan bukti empiris dari hipotesis dimana perusahaan dengan total aset lebih kecil, lebih sedikit juga pengungkapan tanggung jawab sosial.

Perusahaan dengan total aset diatas rata rata di tahun 2018 adalah ANTAM (>33 Triliun), PSAB ( $>13$ triliun rupiah), TINS ( $>15$ triliun rupiah), BYAN (>16 triliun rupiah). Ketiga perusahaan memiliki rata - rata persentase CSR dari tahun 2018 luas. Ketiga perusahaan adalah ANTM persentase CSR (70\%), TINS (43\%), BYAN (33\%). Satu perusahaan yang bertolak belakang dengan HA adalah perusahaan PSAB (12\%). Pada tahun 2018 terdapat 6 perusahaan yang memiliki total aset perusahaan dibawah rata rata, adapun keenam perusahaan ini sama seperti tahun sebelumnya. Keenam perusahaan ini adalah BSSR ( $>3,5$ triliun rupiah), CITA $(>3,2$ triliun rupiah), DKFT ( $>2,6$ triliun rupiah), APEX $(>7,4$ triliun rupiah), ARTI ( $>2,6$ triliun rupiah), PKPK (>127 miliar rupiah). Jika dihubungkan kepada pengungkapan tanggung jawab sosial terdapat 1 perusahaan yang memenuhi HA dimana ukuran perusahaan berpengaruh terhadap CSR. BSSR memiliki persentase CSR cukup tinggi $(38,46)$ sesuai dengan total aset yang dimiliki. Hal ini sesuai dengan bukti empiris dari hipotesis dimana perusahaan dengan total aset lebih kecil, lebih sedikit juga pengungkapan tanggung jawab sosial.

Perusahaan dengan total asset diatas rata rata di tahun 2019 adalah ANTM dengan total rata - rata total asset (>30 triliun rupiah), PSAB $(>13$ triliun rupiah), TINS ( $>20$ triliun rupiah), BYAN (>17 triliun rupiah). Ketiga perusahaan memiliki rata - rata presentase CSR dari tahun 2017 - 2019 yang tinggi adalah ANTM presentase CSR (58\%), TINS (43\%), BYAN (33\%). Satu perusahaan yang bertolak belakang dengan HA adalah perusahaan PSAB (11\%). Total aset perusahaan dalam jutaan rupiah yang dibawah rata - rata pada tahun 2019 terdapat 6 perusahaan. Keenam perusahaan ini adalah BSSR ( $>3,4$ rupiah), CITA $(>3,8$ triliun rupiah), DKFT ( $>2,6$ Triliun rupiah), APEX $(>6,9$ triliun rupiah), ARTI (1,7 triliun rupiah), PKPK (>71 miliar rupiah). Jika dihubungkan kepada pengungkapan tanggung jawab sosial terdapat 1 perusahaan yang memenuhi HA dimana ukuran perusahaan berpengaruh terhadap CSR. BSSR memiliki persentase CSR cukup luas $(33,33)$ sesuai dengan total aset yang dimiliki. Hal ini sesuai dengan bukti empiris dari hipotesis dimana perusahaan dengan total aset lebih kecil, lebih sedikit juga pengungkapan tanggung jawab sosial.

Selanjutnya adalah pembahasan dari unsur karakteristik perusahaan yang adalah variabel independen. Berikut tabel gambaran data ukuran dewan direksi : 
Tabel 4. Gambaran Data Ukuran Dewan Direksi

\begin{tabular}{|l|l|l|l|l|}
\hline \multirow{2}{*}{ No } & Kode & \multicolumn{3}{|l|}{ Jumlah Anggota Dewan Direksi } \\
\cline { 3 - 5 } & Perusahaan & $\mathbf{2 0 1 7}$ & $\mathbf{2 0 1 8}$ & $\mathbf{2 0 1 9}$ \\
\hline 1 & ANTM & 6 & 6 & 6 \\
\hline 2 & CITA & 3 & 3 & 4 \\
\hline 3 & DKFT & 3 & 3 & 3 \\
\hline 4 & PSAB & 5 & 5 & 3 \\
\hline 5 & TINS & 5 & 5 & 8 \\
\hline 6 & APEX & 4 & 4 & 4 \\
\hline 7 & ARTI & 4 & 3 & 3 \\
\hline 8 & PKPK & 2 & 2 & 2 \\
\hline 9 & BSSR & 6 & 8 & 8 \\
\hline 10 & BYAN & 9 & 9 & 7 \\
\hline Rata-Rata & $\mathbf{4 , 7}$ & $\mathbf{4 , 8}$ & $\mathbf{4 , 8}$ \\
\hline Std. Deviasi & $\mathbf{2 , 0}$ & $\mathbf{2 , 3}$ & $\mathbf{2 , 3}$ \\
\hline \multicolumn{2}{|l}{ Tertinggi } & $\mathbf{9}$ & $\mathbf{9}$ & $\mathbf{8}$ \\
\hline \multicolumn{2}{|l|}{ Terendah } & $\mathbf{2}$ & $\mathbf{2}$ & $\mathbf{2}$ \\
\hline
\end{tabular}

Sumber : Hasil pengolahan data dari Laporan Tahunan periode $2017-2019$

Analisis deskriptif menghasilkan bahwa rata-rata anggota dewan direksi perusahaan pertambangan terdaftar yaitu 5 anggota dewan direksi. Tahun 2017 - 2018 BYAN memiliki jumlah anggota dewan direksi terbanyak yaitu sembilan, dan di tahun 2019 yaitu BSSR sebanyak delapan orang anggota. Hanya satu perusahaan yang memiliki ukuran dewan direksi berjumlah dua orang yaitu PKPK. Artinya hampir seluruh perusahaan pertambangan terdaftar memiliki anggota direksi yang melebihi jumlah minimum. Undang-Undang Perseroan Terbatas Nomor 40 Tahun 2007 tentang Perseroan Terbatas pada pasal 92 ayat 1 sampai 6 , dewan direksi yang terpilih biasanya beranggotakan dua atau lebih dan sudah termasuk presiden direktur. Menurut Kabir \& Thai (2017) jumlah anggota dewan direksi yang besar akan membantu dalam pelaksanaan dan perluasan pengungkapan tanggung jawab sosial. Ukuran dewan direksi mempengaruhi penentuan keputusan yang dapat berdampak pada kinerja perusahaan. Ukuran dewan direksi yang sedikit memudahkan dalam pencapaian kesepakatan, sedangkan ukuran dewan direksi yang besar biasanya terdapat keputusan beragam. Ukuran dewan direksi besar dapat membantu meningkatkan performa perusahaan dan efektivitas pemantauan manajer yang akan berdampak pada pengungkapan tanggung jawab sosial (Kabir \& Thai, 2017, p. 235).

Hasil penelitian ini sejalan dengan penelitian yang dilakukan oleh Krisna \& Suhardianto (2016), Matuszak, Różańska, \&
Macunda (2019), Kabir \& Thai (2017) yang dimana terdapat pengaruh ukuran dewan direksi terhadap pengungkapan tanggung jawab sosial. Menurut Krisna \& Suhardianto (2016) dewan direksi sebagai tingkat tertinggi dari manajemen perusahaan bertanggung jawab atas perolehan legitimasi dari seluruh pemangku kepentingan. Ukuran dewan direksi akan mencerminkan mekanisme tata kelola perusahaan, karena setiap keputusan yang dibuat akan mempertimbangkan pendapat dari setiap anggota direksi. Ukuran dewan direksi yang besar akan membantu pelaksanaan pengungkapan tanggung jawab sosial (Krisna \& Suhardianto, 2016, p. 121). Adanya pengaruh ukuran dewan direksi terhadap pengungkapan tanggung jawab sosial juga diperkuat oleh kondisi kelompok perusahaan pertambangan terdaftar. Kondisi perusahaan pertambangan dengan dimensi anggota dewan direksi yang diatas dan dibawah rata - rata setiap tahunnya berbeda.

Ukuran dewan direksi diatas rata - rata $>4$ pada tahun 2017 ditemukan 5 perusahaan. Perusahaan dengan ukuran dewan direksi diatas rata - rata adalah ANTM (6 anggota), PSAB (5 anggota), TINS (5 anggota), BSSR (6 anggota), BYAN ( 9 anggota). Terdapat 1 perusahaan yang memiliki anggota dewan direksi $>4$ tetapi melakukan pengungkapan CSR dibawah rata rata. PSAB dengan persentase pengungkapan tanggung jawab sosial di tahun 2017 sebesar (14\%). Sedangkan di tahun 2017 terdapat 5 perusahaan yang memiliki ukuran dewan direksi dibawah rata - rata. Ketiga perusahaan ini adalah CITA (3 anggota), DKFT (3 anggota), APEX (4 anggota), ARTI (4 anggota), PKPK (2 anggota). Jika dilihat perusahaan ARTI memiliki anggota dewan direksi di tahun 2017 berjumlah 4 anggota dan memiliki persentase CSR (14\%). Selanjutnya pada PKPK memiliki anggota dewan direksi yang kecil yaitu 2 anggota dan memiliki persentase CSR (4\%). Ketiga DKFT memiliki jumlah anggota dewan direksi 3 orang dan memiliki persentase CSR (24\%). Selanjutnya CITA memiliki anggota dewan direksi 3 orang dan memiliki persentase CSR diatas rata-rata CSR tahun 2017 (26\%). Terakhir pada PKPK memiliki anggota dewan direksi yang kecil yaitu 2 anggota dan memiliki 
persentase CSR (4\%). Hal ini sesuai dengan bukti empiris dari hipotesis dimana perusahaan dengan anggota dewan direksi kecil umumnya lebih sedikit mengungkapkan tanggung jawab sosial.

Selanjutnya di tahun 2018 perusahaan yang memiliki anggota dewan direksi diatas rata rata sama dengan tahun sebelumnya. Terdapat penambahan anggota dewan direksi di 1 perusahaan yaitu BSSR (6 anggota ke 8 anggota). Terdapat penurunan pengungkapan CSR di tahun 2018 perusahaan PSAB yang memiliki 5 anggota dewan direksi dari $(14 \%$ ke $12 \%)$. Jika dibandingkan dengan keempat perusahaan terdapat peningkatan pengungkapan CSR dari tahun 2017 ke 2018. Keempat perusahaan ini adalah ANTM dengan 6 anggota (52\% ke 70\%), TINS 5 anggota (42\% ke 43\%), BSSR 8 anggota (27\% ke $38 \%$ ). Artinya sejalan dengan penerimaan HA anggota dewan direksi berpengaruh terhadap pengungkapan CSR. Sedangkan di tahun 2018 perusahaan yang memiliki anggota di bawah ratarata, terdapat 4 perusahaan yang mengalami peningkatan pengungkapan CSR. CITA dan DKFT tetap memiliki 3 anggota dewan direksi dan mengalami peningkatan persentase CSR, dimana CITA (26\% ke 28\%) dan DKFT (24\% ke 32\%). APEX tetap memiliki 4 anggota dewan direksi dan mengalami penurunan pengungkapan CSR $(21 \%$ ke 16). Selanjutnya pada perusahaan ARTI terjadi pengurangan anggota dewan direksi dari 4 anggota menjadi 3 anggota direksi, tetapi terjadi peningkatan CSR (14\% ke 19\%). Terakhir perusahaan yang memiliki anggota dewan direksi dibawah rata - rata di tahun 2018 adalah PKPK dengan 2 anggota dewan direksi mengalami peningkatan CSR (3\% ke 5\%).

Selanjutnya untuk tahun 2019 terdapat 4 perusahaan yang memiliki anggota dewan direksi diatas rata - rata yaitu ANTM (6 anggota), TINS (8 anggota), BSSR (8 anggota), BYAN (7 anggota). Keempat perusahaan ini melakukan pengungkapan CSR diatas rata- rata, hal ini sesuai dengan Hipotesis alternative (HA) dimana semakin banyak anggota dewan direksi semakin luas pengungkapan CSR. Keempat perusahaan ini adalah ANTM (58\%),

TINS (43\%), BSSR (33\%), dan BYAN (33\%). Perusahaan yang memiliki anggota dewan direksi dibawah rata - rata di tahun 2019 terdapat 6 perusahaan. Keenam perusahaan ini adalah CITA (25\%), DKFT (26\%), PSAB (11\%), APEX (17\%), ARTI (17\%), dan PKPK (16\%). Perusahaan di tahun 2019 yang memiliki CSR dengan presentase terkecil adalah PSAB (11\%) dengan jumlah anggota dewan direksi yaitu 3 anggota.

Selanjutnya adalah pembahasan dari unsur karakteristik perusahaan yang adalah variabel independen. Berikut tabel gambaran data kepemilikan manajerial :

Tabel 5.Gambaran Data Kepemilikan Manajerial

\begin{tabular}{|c|c|c|c|c|}
\hline \multirow{2}{*}{ No } & \multirow{2}{*}{$\begin{array}{l}\text { Kode } \\
\text { Perusahaan }\end{array}$} & \multicolumn{3}{|c|}{ Kepemilikan Manajerial (\%) } \\
\hline & & 2017 & 2018 & 2019 \\
\hline 1 & ANTM & 0,013 & 0,013 & 0,009 \\
\hline 2 & CITA & 2,610 & 2,610 & 2,670 \\
\hline 3 & DKFT & 2,780 & 2,790 & 2,780 \\
\hline 4 & PSAB & 92,500 & 92,500 & 92,500 \\
\hline 5 & TINS & 0,012 & 0,012 & 0,012 \\
\hline 6 & APEX & 0,001 & 0,001 & 0,001 \\
\hline 7 & ARTI & 0,290 & 0,290 & 0,290 \\
\hline 8 & PKPK & 39,990 & 39,990 & 35,950 \\
\hline 9 & BSSR & 0,098 & 29,997 & 0,003 \\
\hline 10 & BYAN & 13,410 & 63,570 & 59,700 \\
\hline \multicolumn{2}{|r|}{ Rata-Rata } & 15,170 & 23,177 & 19,391 \\
\hline \multicolumn{2}{|r|}{ Std. Deviasi } & 29,905 & 32,896 & 32,774 \\
\hline \multicolumn{2}{|r|}{ Tertinggi } & 92,500 & $\mathbf{9 2 , 5 0 0}$ & $\mathbf{9 2 , 5 0 0}$ \\
\hline \multicolumn{2}{|r|}{ Terendah } & 0,001 & 0,001 & 0,001 \\
\hline
\end{tabular}

Sumber : Hasil pengolahan data dari Laporan Tahunan periode 2017 - 2019

Analisis deskriptif menghasilkan bahwa perusahaan pertambangan terdaftar memiliki kepemilikan manajerial yang rendah. Dari 10 perusahaan 6 diantaranya memiliki kepemilikan saham kurang dari 5 persen. Hanya satu perusahaan yang memiliki kepemilikan manajerial yang banyak yaitu sebesar 92\% yaitu PSAB. Sejalan dengan teori dimana kepemilikan manajerial dengan persentase minim mengakibatkan peningkatan pengungkapan tanggung jawab sosial pada perusahaan pertambangan di Indonesia. Kepemilikan manajerial yang besar dalam suatu perusahaan akan menjadikan kinerja manajer lebih baik dalam memaksimalkan kebutuhan perusahaan. Manajer perusahaan juga akan mengungkapkan informasi lebih luas. Tujuannya adalah untuk meningkatkan nama perusahaan, tetapi dalam hal ini manajer kemungkinan akan mengeluarkan biaya untuk pengungkapan yang akan dilakukan. Kepemilikan manajerial menjadikan manajemen dominan di perusahaan dan dapat membuat keputusan 
pengungkapan informasi yang dapat diungkapkan. Hal ini membantu dalam pembuatan keputusan lebih cepat, baik strategi dan peraturan.

Pengujian hipotesis secara parsial ditemukan adanya pengaruh kepemilikan manajerial terhadap pengungkapan tanggung jawab sosial perusahaan pertambangan terdaftar. Penerimaan Hipotesis alternative (HA) sejalan dengan penelitian yang dilakukan oleh Dian Agustia (2018) dimana terdapat pengaruh kepemilikan manajerial terhadap pengungkapan tanggung jawab sosial. Menurut Dian Agustia (2018) kepemilikan manajerial yang besar mengakibatkan perusahaan harus mengungkapkan tanggung jawab sosial lebih lagi. Tetapi hal ini berbeda dengan objek penelitian yang bersifat empiris dapat mempengaruhi kepemilikan manajerial terhadap pengungkapan tanggung jawab sosial (Agustia, Dianawati, \& A., 2018, p. 70). Sesuai dengan uji $t$ yang mengatakan menerima Hipotesis alternative (HA) dimana hasil penelitian memberikan bukti empiris, semakin besar kepemilikan manajerial semakin sedikit pengungkapan tanggung jawab sosial yang dilakukan. Pengaruh kepemilikan manajerial dibuktikan oleh kondisi perusahaan pertambangan terdaftar. Kondisi perusahaan pertambangan dengan dimensi kepemilikan manajerial yang diatas dan dibawah rata-rata setiap tahunnya berbeda.

Kepemilikan manajerial diatas rata - rata (>15\%) pada tahun 2017 ditemukan 2 perusahaan. Kedua perusahaan ini adalah PSAB (92\%) dan PKPK (39\%), dengan persentase pengungkapan CSR di tahun 2017 untuk PSAB (14\%) dan PKPK (3\%). Hal ini sejalan dengan hipotesis dimana semakin besar kepemilikan manajerial semakin kecil pengungkapan tanggung jawab sosial yang dilakukan. Sedangkan yang dibawah rata - rata di tahun 2017 terdapat 8 perusahaan yang memiliki kepemilikan manajerial dengan persentase kecil. 8 perusahaan ini adalah ANTM $(0,013 \%)$, CITA $(2,610 \%)$, DKFT $(24 \%)$, TINS $(0,0012 \%)$, APEX $(0,001 \%)$, BSSR $(0,098 \%)$, BYAN (13\%). Jika dilihat dari tabel 3.30 hanya terdapat 5 perusahaan yang memiliki pengungkapan CSR diatas rata rata. Kelima perusahaan ini adalah BYAN (32\%), CITA (26\%), BSSR (36\%), ANTM (52\%), TINS
(42\%). Artinya kepemilikan manajerial di tahun 2017 ini dikatakan masih minim dan sesuai dengan penerimaan HA. Perusahaan pertambangan yang memiliki persentase kepemilikan manajerial memiliki pengungkapan tanggung jawab sosial cukup luas.

Selanjutnya tahun 2018 terdapat 4 perusahaan yang memiliki kepemilikan manajerial diatas rata - rata. Keempat perusahaan ini adalah PSAB (92\%), PKPK (39\%), BSSR (29\%), BYAN (63\%). PSAB (12\%) dan PKPK (5\%) mengungkapkan CSR dibawah rata-rata, hal ini sejalan dengan hasil hipotesis dimana semakin besar kepemilikan manajerial semakin kecil pengungkapan CSR. Berbeda dengan kedua perusahaan sebelumnya BSSR dan BYAN memiliki persentase CSR diatas rata - rata di tahun 2018. BSSR memiliki persentase CSR (38\%) dan BYAN (33\%). Sedangkan persentase kepemilikan manajerial perusahaan dibawah rata - rata di tahun 2018 terdapat 6 perusahaan. Keenam perusahaan ini adalah ANTM $(0,013 \%)$, CITA $(2,610 \%)$, DKSFT $(2,790 \%)$, TINS $(0,012 \%)$, APEX $(0,001 \%)$, ARTI $(0,290 \%)$. Keempat perusahaan diatas terkecuali APEX dan ARTI, sejalan dengan HA. Terdapat pengaruh kepemilikan manajerial terhadap pengungkapan CSR, dan sejalan dengan semakin kecilnya kepemilikan manajerial akan meningkatkan CSR.

Terakhir di tahun 2019 terdapat 3 perusahaan dengan persentase diatas rata - rata kepemilikan manajerial. Ketiga perusahaan ini adalah PSAB dengan persentase kepemilikan manajerial (92\%), PKPK (35\%) dan BYAN (59\%). Sama dengan tahun - tahun sebelumnya PSAB dan PKPK memiliki persentase CSR yang rendah, PSAB di tahun 2019 (11\%) dan (16\%). Artinya PSAB dan PKPK tidak sejalan dengan hasil hipotesis parsial dan dipengaruhi juga oleh keadaan sumber daya perusahaan yang minim. BYAN memiliki persentase pengungkapan diatas rata - rata sebesar (33\%), hal ini serupa dengan tahun sebelumnya. Untuk BYAN sejalan dengan anomali di tahun sebelumnya dimana hampir seluruh dewan direksi memiliki kepemilikan saham manajerial. Selanjutnya di tahun 2019 terdapat 7 perusahaan yang memiliki persentase kepemilikan manajerial dibawah rata - rata dan 
terbilang sangat kecil yaitu tidak ada yang lebih dari $>3$. Ketujuh perusahaan ini adalah ANTM $(0,009 \%)$, CITA $(2,670 \%)$, DKFT $(2,780 \%)$, TINS $(0,012 \%)$, APEX $(0,001 \%)$, ARTI $(0,290 \%)$, $\operatorname{BSSR}(0,003 \%)$. Jika dilihat dari presentase rata rata CSR di tahun 2019, dari ketujuh perusahaan ini hanya ANTM, TINS, dan BSSR yang melebihi rata - rata.

\section{Uji Verifikatif}

Pengujian akan dilakukan melalui tahapan sebagai berikut; (1) pengujian asumsi klasik, (2) interpretasi hasil estimasi model regresi, (3) koefisien determinasi serta (4) pengujian hipotesis. Pengolahan data dilakukan dengan bantuan software IBM SPSS Statistics 22.0 dan hasil selengkapnya disajikan berikut ini.

\section{Uji Asumsi Klasik}

Sebelum dilakukan pengujian hipotesis menggunakan analisis regressi linier, ada beberapa asumsi yang harus terpenuhi agar kesimpulan dari regresi tersebut tidak bias, diantaranya adalah uji normalitas, uji multikolinieritas, uji autokorelasi dan uji heteroskedastisitas.

\section{Uji Normalitas}

Uji normalitas dilakukan untuk mengetahui apakah hasil estimasi model regresi berdistribusi secara normal. Model regresi yang baik adalah yang mempunyai distribusi normal atau mendekati normal. Pada penelitian ini, untuk mendeteksi apakah model regresi berdistribusi normal atau tidak dilakukan dengan menggunakan uji Kolmogorov-Smirnov dan analisis grafik normal probability plot. Pada prinsipnya normalitas dapat dideteksi dengan melihat nilai Asymp Sig pada uji Kolmogorov-Smirnov, apabila lebih besar dari 0,05 maka model regresi dinyatakan normal (Field, 2009, p. 148).
Tabel 6. Uji Asumsi Klasik Normalitas

\begin{tabular}{|l|c|c|}
\hline \multicolumn{2}{|c|}{ One-Sample Kolmogorov-Smirnov Test } \\
\hline \multicolumn{2}{|c|}{} & $\begin{array}{c}\text { Unstandardized } \\
\text { Residual }\end{array}$ \\
\hline \multirow{2}{|c|}{$\mathrm{N}$} & 30 \\
\hline \multirow{2}{*}{$\begin{array}{l}\text { Pormal } \\
\text { Most Extremeters }\end{array}$} & $\begin{array}{c}\text { Std. } \\
\text { Deviation }\end{array}$ &, 0000000 \\
\cline { 2 - 3 } & Absolute &, 072 \\
\cline { 2 - 3 } & Positive &, 072 \\
\cline { 2 - 3 } & Negative &,- 061 \\
\hline \multicolumn{2}{|c|}{ Test Statistic } &, 072 \\
\hline \multicolumn{2}{|c|}{ Asymp. Sig. (2-tailed) } &, $200^{\mathrm{c}, \mathrm{d}}$ \\
\hline
\end{tabular}

Sumber: output IBM SPSS Statistics 22.

Dilihat tabel 6 dapat dilihat nilai signifikansi (Asymp. Sig. (2-tailed)) dari uji Kolmogorov-Smirnov sebesar 0.200 dan lebih besar dari 0.05 . Karena nilai signifikansi uji Kolmogorov-Smirnov lebih besar dari 0.05 maka dapat disimpulkan bahwa model regresi memenuhi asumsi normalitas. Secara visual gambar grafik normal probability plot dapat dilihat pada gambar 1 berikut :

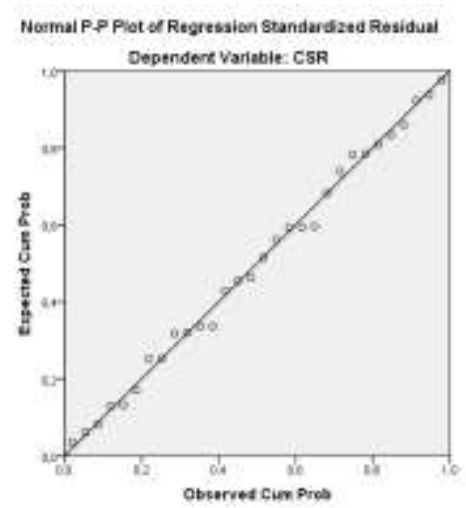

Gambar 1.Grafik Normal Probability P-Plot Sumber : output IBM SPSS statistic 22

Gambar diatas memperkuat kesimpulan bahwa model regresi yang diperoleh berdistribusi normal, dimana sebaran data masih berada disekitar garis diagonal.

\section{Uji Multikolinieritas}

Uji multikolinieritas hanya digunakan pada analisis regresi linier berganda, untuk mendeteksi adanya hubungan yang kuat di antara sesama variabel independen. Pada penelitian ini digunakan nilai variance inflation factors (VIF) sebagai indikator untuk mendeteksi ada tidaknya multikolinieritas diantara variabel independen. Menurut Gujarati \& Porter (2009, p. 340) diantara 
variabel independen terdapat gejala multikolinieritas jika nilai VIF > 10 .

Tabel 7. Uji Asumsi Multikolinieritas

\begin{tabular}{|l|c|c|}
\hline \multirow{3}{*}{ Coefficients } \\
\hline \multirow{2}{*}{ Model } & Collinearity Statistics \\
\cline { 2 - 3 } & Tolerance & VIF \\
\hline Size &, 721 & 1,387 \\
\hline Direksi &, 724 & 1,382 \\
\hline KM &, 994 & 1,006 \\
\hline
\end{tabular}

Sumber: output IBM SPSS Statistics 22.

Berdasarkan tabel 7 dapat dilihat nilai VIF ketiga variabel independen lebih kecil dari 10 dan nilai tolerance lebih besar dari 0,1 menunjukkan tidak ada korelasi yang cukup kuat antara sesama variabel independen Dengan demikian dapat disimpulkan tidak terdapat multikolinieritas diantara ketiga variabel independen.

\section{Uji Heteroskedastisitas}

Uji heteroskedastisitas digunakan untuk menguji ketidaksamaan varian nilai residual tidak homogen yang mengakibatkan nilai taksiran yang diperoleh tidak konsisten. Pengujian heteroskedastisitas dilakukan menggunakan metode informal dan metode formal. Pada metode informal yaitu menggunakan grafik scatterplot (Gujarati \& Porter, 2009, p. 377) dengan dasar pengambilan keputusannya sebagai berikut.

- Jika ada pola tertentu, seperti titik-titik yang ada membentuk suatu pola tertentu yang teratur (bergelombang, melebar kemudian menyempit), maka terjadi heteroskedastisitas

- Jika tidak ada pola yang jelas, seperti titik-titik menyebar di atas dan di bawah angka 0 pada sumbu Y, maka tidak terjadi heteroskedastisitas

untuk $\begin{array}{cr}\text { Berikut ini disajikan grafik } & \text { scatterplot } \\ \text { menganalisis apakah } & \text { terjadi }\end{array}$ heterokedaktisitas pada model regresi, yaitu dengan melihat grafik scatterplot antara nilai prediksi variabel terikat (ZPRED) dengan redsidualnya (SDRESID).

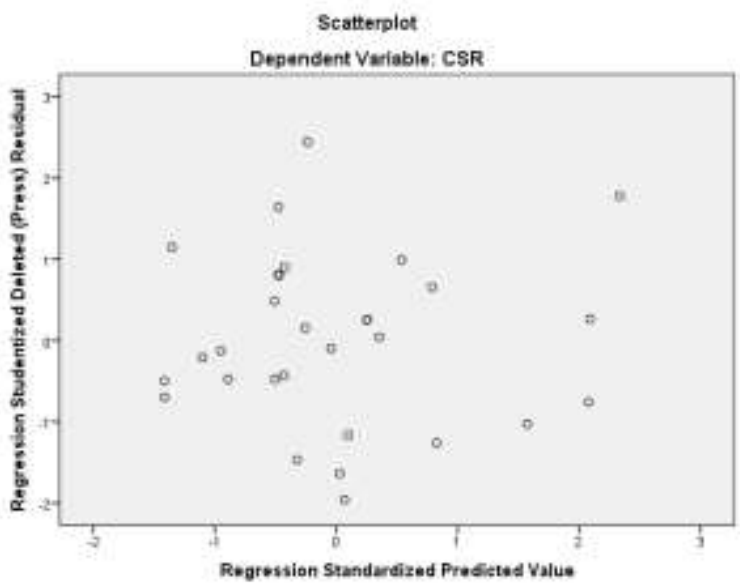

Gambar 2. Grafik Scatterplot Uji Heteroskedastisitas Sumber : output IBM SPSS statistic 22

Pada grafik scatterplot dapat dilihat titiktitik data menyebar secara acak dan tersebar secara merata baik diatas maupun dibawah angka 0 pada sumbu Y. Dengan demikian dapat disimpulkan bahwa tidak terjadi heteroskedastisitas pada model regresi. Selanjutnya pengujian dengan metode formal dilakukan menggunakan uji korelasi rank Spearman, yaitu dengan mengkorelasikan variabel independen terhadap nilai absolut dari residual (Gujarati \& Porter, 2009, p. 380). Apabila ada nilai korelasi yang signifikan pada tingkat kekeliruan $5 \%$, mengindikasikan terjadinya heteroskedastisitas. Pada tabel berikut dapat dilihat nilai signifikansi koefisien korelasi variabel independen terhadap nilai absolut dari residual.

Tabel 8. Hasil Pengujian Asumsi Heteroskedastisitas Correlations

\begin{tabular}{|c|c|c|c|}
\hline & & & Aasolut Residual \\
\hline \multirow[t]{3}{*}{ Spearnan's rho } & Size & $\begin{array}{l}\text { Correlation Coefficient } \\
\text { Sig.(2-tailed) } \\
\text { N }\end{array}$ & $\begin{array}{r}-131 \\
.490 \\
30 \\
\end{array}$ \\
\hline & Direksi & $\begin{array}{l}\text { Correlation Coefficiert } \\
\text { Siq.(2-tiiled) } \\
\mathbb{N}\end{array}$ & $\begin{array}{r}-.100 \\
599 \\
30\end{array}$ \\
\hline & $\mathrm{MM}$ & $\begin{array}{l}\text { Correlation Coeffidert } \\
\text { Sig.(2-triled) } \\
\text { N }\end{array}$ & $\begin{array}{r}-.352 \\
.057 \\
30\end{array}$ \\
\hline
\end{tabular}

Sumber : output IBM SPSS statistic 22

Pada tabel 8 dapat dilihat nilai signifikansi korelasi ketiga variabel independen dengan nilai absolut residual masih lebih besar dari 0,05. Dengan demikian dapat dipastikan bahwa nilai residual yang muncul dari persamaan regresi mempunyai varians yang homogen (tidak terjadi heteroskedastisitas). 


\section{Uji Autokorelasi}

Pada pengujian autokorelasi digunakan uji Durbin-Watson untuk mengetahui ada tidaknya autokorelasi pada model regressi, dan berikut nilai Durbin-Watson yang diperoleh melalui hasil estimasi model regressi.

Tabel 9. Uji Asumsi Autokorelasi

\begin{tabular}{|c|c|}
\hline Model & 1 \\
\hline $\mathrm{R}$ &, $907^{\mathrm{a}}$ \\
\hline R Square &, 822 \\
\hline Adjusted $R$ Square &, 801 \\
\hline Std. Error of the Estimate & 6,86479 \\
\hline Durbin-Watson & 1,792 \\
\hline
\end{tabular}

Sumber: output IBM SPSS Statistics 22

Pada tabel 9. dapat dilihat nilai statistik Durbin-Watson (D-W) hasil regresi sebesar 1,792. kemudian dari tabel $d$ untuk jumlah variabel independen $=3$ dan jumlah pengamatan $\mathrm{n}=30$ diperoleh batas bawah nilai tabel $(\mathrm{dL})=1,214$ dan batas atasnya $(\mathrm{dU})=1,656$. Karena nilai DurbinWatson hasil regressi $(1,792)$ berada diantara dU $(1,656)$ dan 4-dU $(2,344)$, yaitu berada pada daerah tidak ada autokorelasi sehingga dapat disimpulkan tidak terdapat gejala autokorelasi pada model regressi. Karena keempat asumsi regressi sudah diuji dan semuanya terpenuhi, maka dapat disimpulkan bahwa hasil estimasi model regressi sudah memenuhi syarat BLUE (best linear unbias estimation).

\section{Analisis Regresi Linier Berganda}

Model persamaan regresi linier berganda digunakan untuk mengestimasi seberapa besar perubahan pengungkapan tanggungjawab sosial (CSR) yang disebabkan oleh perubahan variabel independen ukuran perusahaan (Size), ukuran dewan direksi (Direksi), dan kepemilikan manajerial (KM). Hasil estimasi persamaan model regresi linier berganda menggunakan software IBM SPSS Statistics 22 diperoleh output sebagai berikut.
Tabel 10. Hasil Estimasi Regresi Linier Berganda

\begin{tabular}{|c|c|c|c|c|c|}
\hline \multirow[t]{2}{*}{ Model } & \multicolumn{2}{|c|}{$\begin{array}{c}\text { Unstandardized } \\
\text { Coefficients }\end{array}$} & \multirow{2}{*}{$\begin{array}{l}\text { Stand } \\
\text { ardize } \\
d \\
\text { Coeffi } \\
\text { cients } \\
\text { Beta }\end{array}$} & \multirow[t]{2}{*}{$\mathrm{t}$} & \multirow[t]{2}{*}{ Sig. } \\
\hline & B & $\begin{array}{l}\text { Std. } \\
\text { Error }\end{array}$ & & & \\
\hline (Constant) & 14,050 & 3,221 & & 4,361 &, 000 \\
\hline Size & 1,089 & 160 & ,663 & 6,801 & ,000 \\
\hline Direksi & 1,737 & ,709 & ,238 & 2,449 & ,021 \\
\hline KM &,- 232 & ,041 &,- 466 & $-5,613$ & ,000 \\
\hline
\end{tabular}

Berdasarkan nilai unstandardized coefficients seperti disajikan pada tabel 10, maka dapat dibentuk persamaan regresi linier berganda sebagai berikut.

$$
Y=14,050+1,089 X_{1}+1,737 X_{2}-0,232
$$

$\mathbf{X}_{3}$

Dimana :

$\mathrm{Y}=$ Pengungkapan tanggungjawab sosial (\%)

$\mathrm{X}_{1} \quad=$ Ukuran perusahaan (triliun rupiah)

$\mathrm{X}_{2} \quad=$ Ukuran dewan direksi (orang)

$\mathrm{X}_{3}=$ Kepemilikan manajerial $(\%)$

Melalui hasil persamaan regresi linier berganda tersebut, koefisien masing-masing variabel independen dapat diinterpretasikan sebagai berikut.

a. Konstanta sebesar 14,050 menunjukkan nilai rata-rata pengungkapan tanggung jawab sosial (CSR), apabila ukuran perusahaan (Size), ukuran dewan direksi (Direksi), dan kepemilikan manajerial (KM) bernilai nol. Artinya ketika total aset, jumlah anggota dewan direksi, kepemilikan manajerial bernilai nol, maka rata-rata pengungkapan tanggung jawab sosial perusahaan hanya sebesar 14,05.

b. Ukuran perusahaan (Size) memiliki koefisien bertanda positif sebesar 1,089 menunjukkan bahwa setiap peningkatan total aset sebesar 1 triliun rupiah diprediksi akan meningkatkan pengungkapan tanggung jawab sosial sebesar $1,089 \%$. Artinya perusahaan dengan ukuran (Size) lebih besar cenderung lebih banyak melakukan pengungkapan tanggung jawab sosial. 
c. Ukuran dewan direksi (Direksi) memiliki koefisien bertanda positif sebesar 1,737 menunjukkan bahwa setiap peningkatan jumlah anggota dewan direksi sebanyak 1 orang diprediksi akan meningkatkan pengungkapan tanggung jawab sosial sebesar $1,737 \%$. Artinya perusahaan dengan jumlah anggota dewan direksi lebih banyak cenderung lebih banyak melakukan pengungkapan tanggung jawab sosial.

d. Kepemilikan manajerial (KM) memiliki koefisien bertanda negatif sebesar 0,232 menunjukkan bahwa setiap peningkatan kepemilikan manajerial sebesar $1 \%$ diprediksi akan menurunkan pengungkapan tanggung jawab sosial sebesar 0,232\%. Artinya perusahaan dengan kepemilikan manajerial lebih sedikit cenderung lebih banyak melakukan pengungkapan tanggung jawab sosial.

\section{Analisis Koefisien Determinasi}

Selanjutnya dihitung koefisien determinasi untuk mengetahui seberapa besar pengaruh ukuran perusahaan, ukuran dewan direksi, dan kepemilikan manajerial terhadap pengungkapan tanggung jawab sosial. Nilai koefisien determinasi diperoleh melalui hasil pengolahan menggunakan software IBM SPSS Statistics 22 seperti disajikan pada tabel berikut:

Tabel 11. Koefisien Determinasi Simultan

\begin{tabular}{|c|c|}
\hline Model & 1 \\
\hline $\mathrm{R}$ &, $907^{\mathrm{a}}$ \\
\hline $\mathrm{R}$ Square &, 822 \\
\hline Adjusted $R$ Square &, 801 \\
\hline Std. Error of the Estimate & 6,86479 \\
\hline Durbin-Watson & 1,792 \\
\hline
\end{tabular}

Sumber: output IBM SPSS Statistics 22

Pada tabel di atas dapat dilihat nilai koefisien determinasi (R Square) sebesar 0,822 menunjukkan bahwa ukuran perusahaan, ukuran dewan direksi, dan kepemilikan manajerial secara simultan memberikan kontribusi atau pengaruh sebesar $82,2 \%$ terhadap pengungkapan tanggung jawab sosial pada perusahaan pertambangan yang tercatat di Bursa Efek Indonesia. Sedangkan sisanya yaitu sebesar $17,8 \%$ merupakan pengaruh faktor lain di luar ukuran perusahaan, ukuran dewan direksi, dan kepemilikan manajerial.

\section{Uji Hipotesis simultan (Uji F)}

Selanjutnya untuk membuktikan apakah ukuran perusahaan, ukuran dewan direksi, dan kepemilikan manajerial secara simultan berpengaruh terhadap pengungkapan tanggung jawab sosial, dilakukan uji signifikansi dengan hipotesis statistik sebagai berikut:

H0 : Semua $\beta \mathrm{i}=0$ : Ukuran perusahaan, ukuran dewan direksi, dan kepemilikan manajerial secara simultan tidak berpengaruh terhadap pengungkapan tanggung jawab sosial.

Ha: Ada $\beta i \neq 0$ : Ukuran perusahaan, ukuran dewan direksi, dan kepemilikan manajerial secara simultan berpengaruh terhadap pengungkapan tanggung jawab sosial.

Untuk menguji hipotesis tersebut digunakan uji simultan melalui uji $\mathrm{F}$ yang diperoleh melalui tabel Anova seperti disajikan pada tabel 12 .

\begin{tabular}{|c|c|c|c|c|c|}
\multicolumn{8}{|c|}{ Tabel 12. Tabel ANOVA } \\
\hline Model & $\begin{array}{c}\text { Sum of } \\
\text { Squares }\end{array}$ & df & $\begin{array}{c}\text { Mean } \\
\text { Square }\end{array}$ & F & Sig. \\
\hline Regression & 5653,384 & 3 & 1884,461 & 39,988 &, $000^{\mathrm{b}}$ \\
\hline Residual & 1225,260 & 26 & 47,125 & & \\
\hline Total & 6878,643 & 29 & & & \\
\hline
\end{tabular}

Sumber: output IBM SPSS Statistics 22

Pada tabel 12 dapat dilihat nilai dilihat nilai Fhitung sebesar 39,988 dengan nilai signifikansi mendekati nol. Kemudian nilai Ftabel pada tingkat signifikansi 5\% dan derajat bebas 3 dan 26 adalah sebesar 2,975. Kriteria uji yang digunakan adalah sebagai berikut :

Jika Fhitung > ttabel, maka H0 ditolak (signifikan) Jika Fhitung $\leq$ Ftabel, maka H0 diterima (tidak signifikan)

Karena Fhitung $(39,988)$ lebih besar dari Ftabel $(2,975)$ dan nilai signifikansi lebih kecil dari 0,05 , maka pada tingkat kekeliruan 5\% diputuskan untuk menolak Ho sehingga Ha diterima. Dengan demikian dapat disimpulkan bahwa ukuran perusahaan, ukuran dewan direksi, dan kepemilikan manajerial secara simultan berpengaruh terhadap pengungkapan tanggung jawab sosial pada perusahaan pertambangan yang tercatat di Bursa Efek Indonesia. 
Secara visual daerah penerimaan dan penolakan Ho pada uji pengaruh bahwa ukuran perusahaan, ukuran dewan direksi, dan kepemilikan manajerial terhadap pengungkapan tanggung jawab sosial dapat dilihat pada grafik berikut.

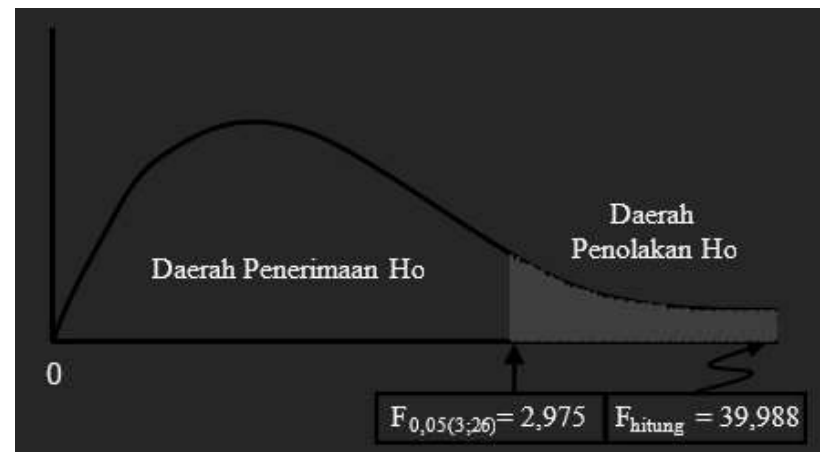

Gambar 3. Grafik Daerah Penerimaan dan Penolakan Ho Pada Uji Pengaruh Simultan

Sumber : output IBM SPSS statistic 22

Pada grafik diatas dapat dilihat nilai Fhitung $(39,988)$ jatuh pada daerah penolakan Ho, sehingga disimpulkan bahwa bahwa ukuran perusahaan, ukuran dewan direksi, dan kepemilikan manajerial secara simultan berpengaruh terhadap pengungkapan tanggung jawab sosial pada perusahaan pertambangan yang tercatat di Bursa Efek Indonesia.

Hasil penelitian, secara simultan atau Uji statistik F ditemukan hasil nilai signifikansi 0,000 lebih kecil dari alfa 5\% yang menerima Hipotesis Alternatif. Artinya terdapat pengaruh ukuran perusahaan (X1), ukuran anggota direksi (X2), kepemilikan manajerial (X3) secara simultan terhadap CSR. Hasil persamaan regresinya adalah $\mathrm{Y}=14,050+1,089 \mathrm{X} 1+1,737 \mathrm{X} 2-0,232 \mathrm{X} 3$. Untuk koefisien ukuran perusahaan (X1) sebesar 1,089, artinya setiap kali X1 menambah 1 unit maka akan meningkatkan pengungkapan CSR sebesar 1,089. Untuk koefisien ukuran dewan direksi (X2) sebesar 1,737, artinya setiap kali X2 menambah 1 unit maka akan meningkatkan pengungkapan CSR sebesar 1,737. Untuk koefisien kepemilikan manajerial (X3) sebesar -0,232, artinya setiap kali X3 menambah 1 unit maka akan mengurangi pengungkapan CSR sebesar -0,232.

Sejalan dengan penelitian Krisna \& Suhardianto (2016), Agustia, Dianawati, \& A. (2018), dan Kabir \& Thai (2017) dimana karakteristik perusahaan berpengaruh terhadap
CSR. Karakteristik perusahaan terbagi kedalam tiga dimensi. Masing-masing dimensi memiliki pengaruh terhadap pengungkapan tanggung jawab sosial. Menurut Krisna \& Suhardianto (2016) ukuran perusahaan mempengaruhi besarnya upaya dalam mendapatkan legitimasi dari publik. Sejalan dengan teori legitimasi dimana perusahaan berupaya untuk melakukan suatu tindakan yang dapat diterima oleh lingkungan masyarakat salah satunya dengan menerapkan pengungkapan tanggung jawab sosial. Selanjutnya dimensi ukuran dewan direksi, dimana ukuran anggota dewan direksi akan mempengaruhi pelaksanaan tanggungjawab sosial (Krisna \& Suhardianto, 2016, pp. 120-121).

Menurut Kabir \& Thai (2017) ukuran dewan direktur mempengaruhi penentuan keputusan. Ketika ukuran dewan direktur yang kecil memudahkan dalam mencapai suatu kesepakatan. Tetapi mengurangi kinerja masingmasing dewan direksi dikarenakan banyaknya tugas dan tanggung jawab yang dirangkap. Sedangkan dengan ukuran dewan direksi yang besar dapat membantu dalam efektivitas pemantauan kinerja manajer. Ukuran dewan direksi yang besar juga dapat membantu perusahaan dalam meningkatkan performa keuangan perusahaan. Tetapi pada ukuran dewan direksi yang besar mengakibatkan keputusan beragam. Masing-masing anggota direksi memiliki keputusan pribadi yang berfokus pada stakeholders. Hal ini mengakibatkan sulitnya ditemukan kesepakatan dalam pembuatan keputusan (Kabir \& Thai, 2017, p. 235). Terakhir adalah dimensi kepemilikan manajerial, menurut Agustia, Dianawati, \& A. (2018) kepemilikan oleh manajemen perusahaan dapat membantu perusahaan dalam pengungkapan informasi (Agustia, Dianawati, \& A., 2018, p. 68).

\section{Uji Hipotesis Parsial (Uji t)}

Hasil pengolahan uji hipotesis dapat dilihat pada tabel 10 di atas. Hipotesis parsial pertama yang akan diuji adalah pengaruh ukuran perusahaan terhadap pengungkapan tanggung jawab sosial. Untuk membuktikan apakah ukuran perusahaan berpengaruh terhadap pengungkapan tanggung jawab sosial, dilakukan uji signifikansi 
dengan hipotesis statistik sebagai berikut:

- $\mathrm{H} 0: \beta 1=0:$ Ukuran perusahaan tidak berpengaruh terhadap pengungkapan tanggung jawab sosial .

- Ha: $\beta 1 \neq 0$ : Ukuran perusahaan berpengaruh terhadap pengungkapan tanggung jawab sosial.

Nilai thitung pengaruh ukuran perusahaan terhadap pengungkapan tanggung jawab sosial sebesar 6,801 dengan nilai signifikansi mendekati nol. Hasil yang diperoleh dari perbandingan thitung dengan ttabel adalah thitung lebih besar dari positif ttabel $(6,801>2,056)$ dan nilai signifikansi lebih kecil dari 0,05, sehingga pada tingkat kekeliruan 5\% diputuskan untuk menolak Ho dan menerima Ha. Dengan demikian dapat disimpulkan bahwa ukuran perusahaan berpengaruh terhadap pengungkapan tanggung jawab sosial pada perusahaan pertambangan yang tercatat di Bursa Efek Indonesia.

Hipotesis parsial kedua yang akan diuji adalah pengaruh ukuran dewan direksi terhadap pengungkapan tanggung jawab sosial. Untuk membuktikan apakah ukuran dewan direksi berpengaruh terhadap pengungkapan tanggung jawab sosial, dilakukan uji signifikansi dengan hipotesis statistik sebagai berikut:

- H0: $\beta 2=0$ : Ukuran dewan direksi tidak berpengaruh terhadap pengungkapan tanggung jawab sosial.

- Ha : $\beta 2 \neq 0$ : Ukuran dewan direksi berpengaruh terhadap pengungkapan tanggung jawab sosial.

Nilai thitung pengaruh ukuran dewan direksi terhadap pengungkapan tanggung jawab sosial sebesar 2,449 dengan nilai signifikansi sebesar 0,021. Hasil yang diperoleh dari perbandingan thitung dengan ttabel adalah thitung lebih besar dari positif ttabel $(2,449>2,056)$ dan nilai signifikansi lebih kecil dari 0.05 , sehingga pada tingkat kekeliruan 5\% diputuskan untuk menolak Ho dan menerima Ha. Dengan demikian dapat disimpulkan bahwa ukuran dewan direksi berpengaruh terhadap pengungkapan tanggung jawab sosial pada perusahaan pertambangan yang tercatat di Bursa Efek Indonesia.

Hipotesis parsial ketiga yang akan diuji adalah pengaruh kepemilikan manajerial terhadap pengungkapan tanggung jawab sosial. Untuk membuktikan apakah kepemilikan manajerial berpengaruh terhadap pengungkapan tanggung jawab sosial, dilakukan uji signifikansi dengan hipotesis statistik sebagai berikut:

- $\mathrm{H} 0: \beta 3=0$ : Kepemilikan manajerial tidak berpengaruh terhadap pengungkapan tanggung jawab sosial.

- Ha : $\beta 3 \neq 0$ : Kepemilikan manajerial berpengaruh terhadap pengungkapan tanggung jawab sosial.

Pada tabel di atas dapat dilihat nilai thitung pengaruh kepemilikan manajerial terhadap pengungkapan tanggung jawab sosial sebesar $-5,613$ dengan nilai signifikansi mendekati nol. Hasil yang diperoleh dari perbandingan thitung dengan ttabel adalah thitung lebih kecil dari negatif ttabel $(-5,613<-2,056)$ dan nilai signifikansi lebih kecil dari 0.05 , sehingga pada tingkat kekeliruan $5 \%$ diputuskan untuk menolak Ho dan menerima Ha. Dengan demikian dapat disimpulkan bahwa kepemilikan manajerial berpengaruh terhadap pengungkapan tanggung jawab sosial pada perusahaan pertambangan yang tercatat di Bursa Efek Indonesia.

\section{KESIMPULAN}

Seluruh perusahaan pertambangan terdaftar sudah menaati Undang - Undang Nomor 40 Tahun 2007 tentang Perseroan Terbatas pasal 74 yang mana mewajibkan perusahaan yang bergerak di bidang sumber daya alam untuk melakukan tanggung jawab sosial. Tetapi pengungkapan yang dilakukan kebanyakan perusahaan pertambangan yang terdaftar masih minim.

Pada tahun 2017 PT Aneka Tambang Tbk memiliki persentase pengungkapan cukup besar. Hal ini didukung dengan banyaknya indikator CSR yang dilaksanakan. Selanjutnya perusahaan yang mengalami kestabilan dalam pengungkapan tanggung jawab sosial adalah PT Timah Tbk dan PT Bayan Resources Tbk dengan indikator yang serupa dari tahun ke tahunnya. Hal ini sejalan dengan teori dimana tanggung jawab sosial berisikan berbagai macam indikator yang merupakan tanggung jawab bisnis oleh perusahaan. Jika dilihat dari pengungkapan 
tanggung jawab sosial seluruh perusahaan, hal yang paling banyak diungkapkan adalah pemberian donasi kepada masyarakat.

Hampir seluruh perusahaan pertambangan memiliki total aset diatas 1 triliun rupiah. Artinya perusahaan pertambangan di Indonesia sebagian besar sudah memiliki total aset cukup besar. Hal ini akan mempengaruhi banyaknya isu CSR yang diungkapkan. Terdapat empat perusahaan pertambangan terdaftar yang mengalami peningkatan total aset setiap tahunnya. Keempat perusahaan ini juga memiliki pengungkapan tanggung jawab sosial dengan rata-rata kecil dan meningkat setiap tahunnya. Hal ini membuktikan perusahaan yang memiliki total aset yang meningkat setiap tahunnya akan mengalami peningkatan pelaksanaan tanggung jawab sosial.

Seluruh perusahaan pertambangan terdaftar memiliki anggota dewan direksi. Sesuai dengan Undang-Undang Perseroan Terbatas Nomor 40 Tahun 2007 tentang Perseroan Terbatas pada pasal 92 ayat 1 sampai 6 yang mengatur anggota dewan direksi. Terdapat satu perusahaan di tahun 2017-2018 memiliki anggota direksi dalam jumlah banyak. Tahun 2019 terdapat dua perusahaan yang memiliki anggota dewan direksi dalam jumlah banyak. Selanjutnya terdapat tiga perusahaan dari tahun 2017 - 2019 memiliki anggota dewan direksi yang tidak berubah jumlahnya.

Hampir seluruh perusahaan pertambangan terdaftar memiliki kepemilikan manajerial dengan persentase tidak dominan. Hanya beberapa perusahaan yang memiliki kepemilikan manajerial yang besar. Sebagian besar memiliki kepemilikan manajerial dengan persentase yang cukup kecil. Hal ini akan mempengaruhi pengungkapan tanggung jawab sosial, dengan bertambah atau berkurangnya persentase kepemilikan manajerial.

Untuk penelitian selanjutnya, dapat dikaji lebih lanjut terkait dengan karakteristik lain dari perusahaan seperti penggunaan unsur profitabilitas, ukuran anggota dewan komisaris dan komite audit, serta kepemilikan asing.

\section{DAFTAR PUSTAKA}

Agustia, D., Dianawati, W., \& A., D. (2018). MANAGERIAL OWNERSHIP, CORPORATE SOCIAL RESPONSIBILITY DISCLOSURE AND CORPORATE PERFORMANCE.

Management of Sustainable Development Sibiu, Volume 10, No.2, 67-71.

Daniri, M. A. (2014). Lead By GCG. Jakarta Pusat: Gagas Bisnis Indonesia.

Field, A. (2009). Discovering Statistics Using SPSS. $(3 r d e d)$ London: SAGE Publications Ltd.

Gujarati, D., \& Porter, D. (2009). Basic Econometrics 5th Edition (5 ed.). New York: McGraw Hill.

Herman. (2018). Manfaat Corporate Social Responsibility oleh Stakeholder Primer dan Sekunder (Studi Kasus Pada PT. Asia Sawit Makmur Jaya Provinsi Riau). Jurnal Ilmiah Manajemen Publik dan Kebijakan Sosial, Vol. 2, No. 2, 264 - 277.

Husaini, H., \& Trinesia, M. (2020). Determinan Pengungkapan Tanggung Jawab Sosial Perusahaan di Indonesia. Jurnal Akuntansi, Vol 10, No 1, 93 - 104.

International Finance Corporation. (2018). INDONESIA CORPORATE GOVERNANCE MANUAL Second Edition. Jakarta: International Finance Corporation.

Ismail, T. H. (2020). Does Egyptian universities disclosure on social responsibility enhance sustainable development? Journal of Humanities and Applied Social Sciences, Vol 2, No 2, 81 - 99.

Kabir, R., \& Thai, H. (2017). Does corporate governance shape the relationship between corporate social responsibility and financial performance? Pacific Accounting Review, Vol 29, No 2, 227 - 258.

Komite Nasional Kebijakan Governance. (2006). PEDOMAN UMUM GOOD CORPORATE GOVERNANCE INDONESIA. Jakarta: Komite Nasional Kebijakan Governance. 
Krisna, A., \& Suhardianto, N. (2016). FaktorFaktor yang Mempengaruhi Pengungkapan Tanggung Jawab Sosial. Jurnal Akuntansi dan Keuangan, Vol 18, No 2, 119 - 127.

Latifah, S. W. (2012). Tanggung Jawab Sosial Berdasarkan ISO 26000 dan Nilai Perusahaan yang Listed di Bursa Efek . Jurnal Ekonomika-Bisnis Vol 03, No 1, 6574.

Matuszak, Ł., Różańska, E., \& Macuda, M. (2019). The impact of corporate governance characteristics on banks' corporate social responsibility disclosure Evidence from Poland. Journal of Accounting in Emerging Economies, Vol 9, No 1, 75-102. Nurleni, N., Bandang, A., Darmawati, \& Amiruddi. (2017). The effect of managerial and institutional ownership on corporate social responsibility disclosure. International Journal of Law and Management, Vol 60, No 4, 979 - 987.

Salehi, M., Tarighi, H., \& Rezanezhad, M. (2017). The relationship between board of directors' structure and company ownership with corporate social resposibility disclosure Iranian angle. Humanomics, Vol 33, No 4, 398-418.

Sekaran, U., \& Bougie, R. (2016). Research Methods for Business. Cichester, West Sussex, United Kingom: John Wiley and Sons Ltd.

Sugiyono. (2017). METODE PENELITIAN KUANTITATIF, KUALITATIF, dan R\&D. BANDUNG: ALFABETA.

Undang - Undang Nomor 40 Tahun 2007 tentang Perseroan Terbatas pasal 74.

Weygandt, J. J., Kimmel, P. D., \& Kieso, D. E. (2015). Financial Accounting. Danvers, United States of America: John Wiley \& Sons, Inc. 